\title{
The relationship between the storage methods and the formation of dentinal defects (cracks)
}

\author{
A relação entre os métodos de armazenamento e a \\ formação de defeitos dentinários (trincas)
}

\author{
Fábio Nakao ARASHIRO' ${ }^{1}$ (D) 0000-0002-0258-4834 \\ Michelle Tavares Galotto NANTES ${ }^{1}$ iD 0000-0001-5674-8884 \\ Pedro Gregol da SILVA ${ }^{1}$ iD 0000-0003-4601-3352 \\ Key Fabiano Souza PEREIRA ${ }^{1}$ iD 0000-0001-5403-9283 \\ Muryllo Eduardo Sales dos SANTOS ${ }^{1}$ iD 0000-0001-8517-4154
}

\section{ABSTRACT}

Objective: This research study aims at conducting an in vitro evaluation of crack formation in freshly extracted teeth after undergoing different storage and decontamination methods. Methods: 60 erupted upper third molars conventionally extracted using forceps \# 210h (quinelato surgical instruments, rio claro - sp) and randomly distributed in three groups ( $\mathrm{n}=30$ ): group 1 - storage in dry environment for 30 days, group 2 - sterilization in autoclave and storage for 30 days in distilled water, and group 3 - 10\% formaldehyde decontamination for 14 days and storage in distilled water for additional 30 days. after the storage period, teeth had their roots transversely sectioned at 2, 4 and $6 \mathrm{~mm}$ below the root apex using a low rotation diamond disk under constant cooling. the evaluation of fragments was performed using a 30-time magnification microscope. Results: Cracks were seen only in group 1 and the chi-square statistical test with $5 \%$ significance level showed a statistically significant difference comparing the dry storage group to the others. Conclusion: The storage of extracted teeth in a dry environment influences the formation of dentinal defects.

Indexing terms: Disinfection. Endodontics. Root canal treatment.

\section{RESUMO}

Objetivo: Avaliar in vitro a formação de trincas em dentes recém-extraídos após a manutenção em diferentes formas de armazenamento e descontaminação. Métodos: foram utilizados 60 terceiros molares superiores erupcionados, que foram extraídos da forma convencional utilizando fórceps $n^{\circ} 210 \mathrm{H}$ (Quinelato instrumentos cirúrgicos, Rio Claro-SP) e aleatoriamente distribuídos em três grupos $(n=30)$ sendo: Grupo 1 - armazenamento em ambiente seco por 30 dias, Grupo 2 - esterilização em autoclave e armazenamento por 30 dias em água destilada e Grupo 3 - descontaminação em formol a 10\% por 14 dias e armazenamento em água destilada por mais 30 dias. Após finalizado os períodos de estocagem, os dentes tiveram suas raízes seccionadas transversalmente em 2, 4 e 6mm aquém do ápice radicular com disco diamantado montado em baixa rotação sob refrigeração constante, e a avaliação dos fragmentos foi realizada com microscópio operatório no aumento de 30x. Resultados: Foram observadas trincas apenas no grupo 1 ,

$\because \nabla$

1 Universidade Federal de Mato Grosso do Sul, Faculdade de Odontologia. Rua Antonio Maria Coelho 4004, Santa Fé, 79021-170, Campo Grande, MS, Brasil. Correspondência para / Correspondence to: FN ARASHIRO. E-mail: <fabionakao@hotmail.com>.

$\checkmark \nabla \nabla$

How to cite this article

Arashiro PN, Nantes MTG, Silva PG, Pereira KFS, Santos MES. The relationship between the storage methods and the formation of dentinal defects (cracks). RGO, Rev Gaúcha Odontol. 2019;67e20190028. http://dx.doi.org/10.1590/1981-86372019000283566 
o teste estatistico Chi-quadrado com nivel de significância de 5\% demonstrou diferença estatisticamente significativa entre o grupo de armazenamento em ambiente seco em relação aos demais. Conclusão: O armazenamento dos dentes extraídos em ambiente seco influencia na formação dos defeitos dentinários.

Termos de indexação: Desinfecção. Endodontia. Tratamento do canal radicular.

\section{INTRODUCTION}

In Dentistry, the search for methods that faithfully simulate the clinical conditions are essential to guarantee the relevance of researches, therefore, many studies use human teeth when conducting them. The use of extracted teeth is essential to consolidate teaching and researches in dental courses. In Brazil, through the Transplantation Law, teeth are, now, considered organs and, then, their source must be known. Therefore, the legal source of teeth supply is a human teeth bank that should store teeth in conditions that keep their chemical, physical and mechanical properties, allowing the accomplishment of research studies with biases control [1].

According to the 2003 guidelines proposed by the US Center for Disease Control and Prevention (CDC), human teeth extracted for teaching or research purposes should be decontaminated prior to use and autoclaved or stored, after extraction, in 10\% formaldehyde solution for a period of 14 days [2].

Teeth preparation, selection and disinfection/ sterilization methods may vary according to the research and the purpose that teeth are used [3]. Although there is not an ideal solution that keep the dental structures with their characteristics unchanged, standardization of the methods applied is necessary to compare the results, since the time and the method that teeth are stored represent important variables [4]. Root canal instrumentation is one of the most important phases of the endodontic treatment, aiming at cleaning and modeling the intracanal space to ensure adequate sealing. The preparation is performed by excising the root dentin by the mechanical action of the endodontic instrument [5]. It is important to mention that some questions arise regarding the side effects that the kinematics applied to the endodontic instruments has on teeth [6].

Endodontic procedures, including instrumentation, cause structural loss and excessive stress to dental remnants, which may lead to crack formation, resulting in vertical root fractures with indication for tooth extraction [7]. Several methodologies have been applied to evaluate the influence of endodontic techniques on the root dentin, such as the observation with magnification of the dentinal defects in the sectioned root fragments [8].

Studies evaluating dentinal defects caused by endodontic preparation through sectioned fragments show a high percentage of crack occurrences, but with conflictive and inconclusive results. Moreover, recent works, in which the specimens were analyzed, before and after the instrumentation stages, through micro computed tomography (micro-CT), have diagnosed the cracks as preexisting to the endodontic intervention, thus, showing a lack of causal relation between the presence of cracks with root canal preparation $[9,10]$.

Studies evaluating the formation of dentinal cracks usually do not mention the storage and the decontamination conditions of the specimens. However, the identification of the condition of the donated teeth is of great importance, since the lack of sample information may lead to inappropriate conclusion [11].

Therefore, considering the contradictory results found in recent studies, reporting on dentinal cracks caused by endodontic preparation, this current research study has evaluated the interference of the storage methods on extracted teeth.

\section{METHODS}

This study was approved by the Ethics Committee of the Federal University of Mato Grosso do Sul (Brazil Platform) under protocol number CAAE:51780315.3.0000.0021. The sample comprised 60 healthy third molars donated by the patient after understanding and accepting the Informed Consent Term (ICT).

For the inclusion criteria, patients who, after anamnesis, clinical and radiographic exams, required extraction of the erupted upper third molars participated in the study. Patients with systemic problems, preventing them to be assisted, were excluded from the study. The surgical sequence consisted of the operating field antisepsis, infiltrative anesthesia with anesthetic Mepivacaine $2 \%$ with epinephrine 1: 100,000 (DFL ${ }^{\circledR}$, Brazil) and extraction applying 
the conventional technique. Initially, the syndesmotone \#1 (Quinelato surgical instruments, Rio Claro-SP) was used to remove the gingiva and expose the amelocemental junction and, them, the process followed with the extraction using forceps \# 210H (Quinelato surgical instruments, Rio ClaroSP). Soon after, the teeth were carefully cleaned with gauze and running water for the periodontal tissue remnants removal.

Immediately after the teeth extraction, the sample was randomly divided into three groups as follows: Group 1: 20 upper third molars stored in dry environment (room temperature) for 30 days; Group 2: 20 upper third molars autoclaved at 121oC 20psi / 40 minutes (HI VAC II - Baumer, Mogi-Mirim SP, Brazil) and stored for 30 days in distilled water; Group 3: 20 upper third molars kept in $10 \%$ formaldehyde for 14 days and stored in distilled water for 30 days.

For the specimen's examination, after the storage period, the teeth were perpendicular sectioned at 2 , 4 and $6 \mathrm{~mm}$ below the root apex using a double-sided diamond disk No. 7020 (KG Sorensen, Barueri SP, Brazil) in low speed micromotor under constant cooling. The sections were washed with distilled water in an ultrasonic tank (Cristófoli - Campo Mourão, Paraná, Brazil) for 180 seconds to remove the smear layer, dried with air jets and stabilized on the glass plate with Zetaplus condensation silicone (Zhermack Dental - Italy) to correct the specimen's inclination for focusing.
The analysis of the dentinal defects was performed by three examiners, through observation using a 30-time magnifying surgical microscope (OPTO - São Carlos SP). In case of questions and/or disagreement between the examiners, considering the presence or not of a dentinal defect, there would be a re-evaluation of the images captured and stored by a digital camera (Canon T3i - Japan).

\section{RESULTS}

The tabulated data were analyzed and submitted to the Chi-square statistical test, establishing a 5\% significance level. Data collected are binary and consisting of the confirmation, or not, of an occurrence. In this study, cracks were the occurrences analyzed, and only group 1 presented cracked roots (figure 1), as shown in table 1. Thus, the dry storage method significantly influenced the number of cracks $(P<0.05)$ in relation to the other groups.

Table 1. Classification of the data collected.

\begin{tabular}{lcccc}
\hline & Group 1 & Group 2 & Group 3 & TOTAL \\
\hline Occurrences & 3 & 0 & 0 & 3 \\
No Occurrences & 17 & 20 & 20 & 57 \\
\hline Total & 20 & 20 & 20 & 60 \\
\hline
\end{tabular}
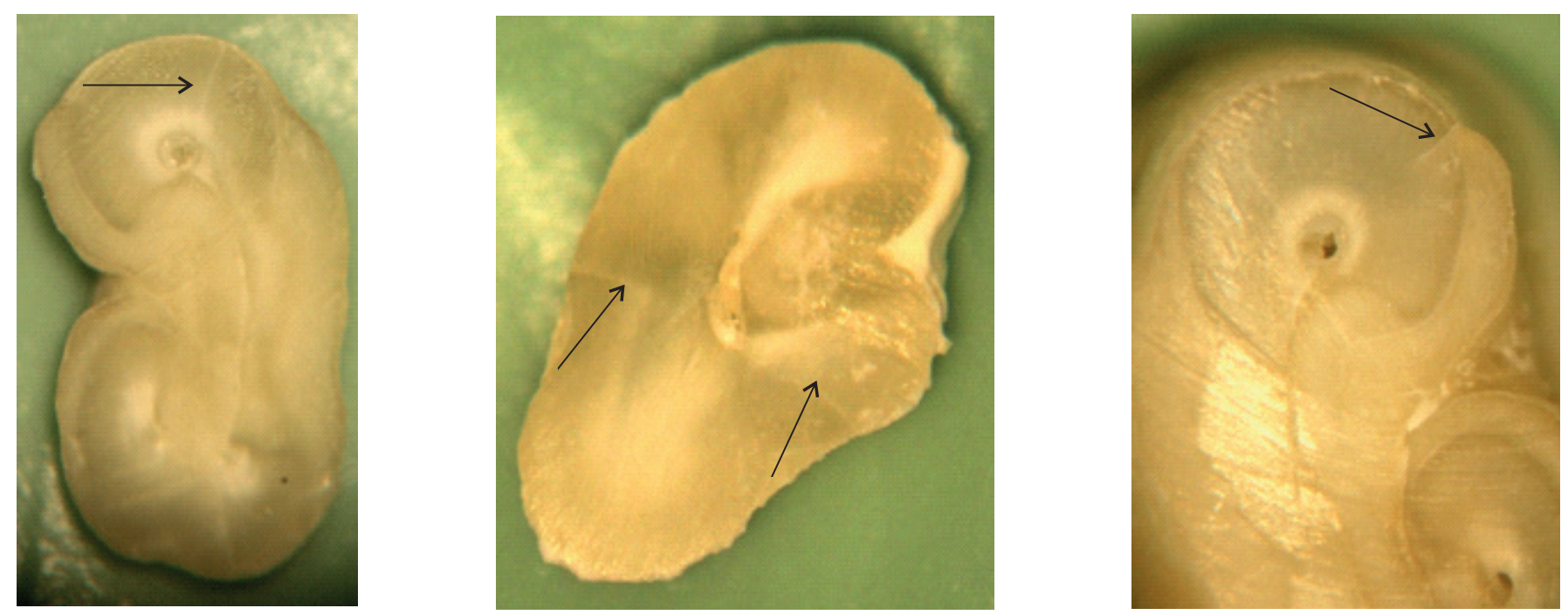

Figure 1. Sections at $6 \mathrm{~mm}$ from the root apex showing dentinal defects (Group 1). 


\section{DISCUSSION}

The lack of standardization methods for extracted teeth decontamination and storage makes it possible the use of several disinfectants $[12,13]$. Although the efficiency of such disinfectants has been investigated, the potential to cause changes to the dental structure is poorly studied and can be a relevant bias to this type of sample [14].

Several studies evaluating dentinal defects in dental roots have reported the correlation between cracks and fractures with endodontic instrumentation $[7,8,15-$ 17] However, studies by De Deus et al. have indicated that defects observed after endodontic instrumentation were already there and, probably, occurred due to inadequate and/or unknown storage conditions [18]. Besides the time and the storage methods, forces generated during extraction are also significant factors to be observed when selecting the sample to be used in surveys that evaluate dentinal defects [19], as teeth less traumatically extracted and immediately stored in a suitable dispensers may present fewer cracks than those from unknown source [20]. In this research study, the erupted third molars were the teeth selected for the study due to the large extraction casuistry, besides offering less surgical complexity in relation to the lower teeth, thus, allowing a better control of the force applied during surgery.

Likewise, most of the works that evaluate dentinal cracks use root sectioning methods and evaluate fragments using magnification $[7,8,16,17]$. Although this methodology destroys the specimen, it enables the visualization and direct evaluation of the defects in the dental structure without the need for prior training of examiners. In this study, several storage and decontamination methods were investigated without performing endodontic instrumentation to observe the relationship between the crack formation and the condition in which the teeth were stored. The results have shown that dentinal defects were found only in the group storage in dry environment for 30 days, confirming the statements of Jameson et al. [21] and Bajaj et al. [22], who concluded that the post-extraction storage method significantly influences the occurrence of cracks, and teeth kept in dry storage tend to present a greater number of cracks. Additionally, according to DeDeus et al. [23] cracks may occur spontaneously even in short storage periods with no moisture.

Contrary to the methods recommended by the CDC (Center for Disease Control and Prevention) for decontamination and storage of extracted teeth, Pimentel et al. [4] and White et al. [24] have stated that the exposure of teeth to $10 \%$ formaldehyde and autoclaving interfere on the physical properties of the dentin. Likewise, Michaud et al. [25] have verified that autoclaving decreases teeth resistance to fracture. However, in this research study, no crack was seen in the specimens treated applying these methods.

In view of the results achieved, further investigation is necessary considering the storage methods of extracted teeth to evaluate dentinal defects, since the results found in this study indicate a significant bias for this research line.

\section{CONCLUSION}

Considering the methodology applied and the results achieved, it can be concluded that the storage of extracted teeth in a dry environment significantly influences the formation of cracks/dentinal defects.

\section{Collaborators}

FN ARASHIRO, investigation, methodology, supervision, writing-original draft. MTG NANTES, investigation, methodology, writing-original draft. PG SILVA, writing-review \& editing, supervision. KFS PEREIRA, supervision, data curation, formal analysis. MES SANTOS, writing-review \& editing.

\section{REFERENCES}

1. Gomes GM, Gomes GM, Pupo YM, Gomes OMM, Schimidt LM, Koslowski Junior VA. Utilização de dentes humanos: aspectos éticos e legais. RGO, Rev Gaúch Odontol. 2013;61:477-83.

2. Centers for Disease Control and Prevention (CDC). Guidelines for infection control in dental healthcare settings MMWR Recomm Rep. 2003;52:1-61.

3. Nassif ACS, Tiei F, Ana PA, Botta SB, Imparato JCP. Estruturação de um banco de dentes humanos. Pesqui Odontol Bras. 2003; 17(supl1):70-74. http://dx.doi.org/10.1590/\$1517-74912003 000500012

4. Pimentel E, Bittencourt LP, Volschan B, Dias K. Armazenamento de dentes extraídos para estudos in vitro: revisão de literatura. RBO. 2002; 59(4): 224-26.

5. Schilder $\mathrm{H}$. Cleaning and shaping the root canal. Dent Clin North Am. 1974;18(2):269-96.

6. Burklein S, Hinschitza K, Dammaschke, Schafer E. Shaping ability and cleaning effectiveness of two single-file systems in severely curved root canals of extracted teeth: reciproc 
and waveone versus mtwo and pro taper. Int Endod J. 2012;45(5):449-461. http://dx.doi.org/10.1111/j.1365-2591.2011. 01996.x

7. Bier CA, Shemesh H, Tonomaru-Filho M, Wesselink PR, WU MK. The ability of different nickel-titanium rotary instruments to induce dentinal damage during canal preparation. J Endod. 2009;35(2):236-38. http://dx.doi.org/10.1016/ j.joen. 2008.10.021

8. Çapar ID, Uysal B, Ok E, Arslan H. Effect of the size of the apical enlargemente with rotary instruments, single-cone filling, post space preparation with drills, fiber post removel, and root canal filling removal on apical crack initiation and propagation. J Endod. 2015;41(2):253-56. http://dx.doi. org/10.1016 / j.joen.2014.10.012

9. De-Deus G, Silva EJNL, Martins J, Souza E, Neves AA, Belladonna FG, et al. Lack of causal relationship between dentinal microcraks and roots canal preparation with reciprocation systems. J Endod. 2014;40(9):1447-50. http:// dx.doi.org/10.1016 / j.joen.2014.02.019

10. De-Deus G, Belladonna FG, Souza EM, Silva EJNL, Neves AA, Alves $\mathrm{H}$, et al. Micro-computed tomographic assessment on the effect of protaper next and twisted file adaptive systems on dentinal cracks. J Endod. 2015;41(7):1116-19. http://dx. doi.org/10.1016/ j.joen.2015.02.012

11. Versiani MA, Souza E, De-Deus G. Critical appraisal of studies on dentinal radicular microcracks in endodontics: methodological issues, contemporary concepts, and future perspectives. Endod Topics. 2015;33:87-156. https://doi. org/10.1111/etp. 12091

12. Dominici JT, Eleazer PD, Clark SJ, Staat RH, Scheetz JP. Disinfection/sterilization of extracted teeth for dental student use. J Dent Educ. 2001;65(11):1278-80.

13. Kaul R, Kaul V, Farooq R, Wazir N, Khateeb S, Malik A, et al. Cut off values of laser fluorescence for different storage methods at different time intervals in comparison to frozen condition: A 1 year in vitro study. J Conserv Dent. 2014;17(2):124. http:// dx.doi.org/10.4103/0972-0707.128043

14. George SW, Pichardo MR, Bergeron BE, Jeansonne BG. The effect of formalina storage on the apical microleakage of obturated canals. J Endod. 2006;32(9):869-871. http://dx. doi.org/10.1016 / j.joen.2006.04.009

15. Shemesh H, Bier C, Wu M, Tanomaru-Filho M, Wesselink P. The effects of canal preparation and filling on the incidence of dentinal defects. Int Endod J. 2009;42(3):208-213. http:// dx.doi.org/10.1111/ j.1365-2591.2008.01502.x
16. Shemesh $H$, Wesselink PR, Wu MK. Incidence of dentinal defects after root canal filling procedures. Int Endod J. 2010;43(11):995-1000. http://dx.doi.org/10.1111/j.1365-2591. 2010.01740.x

17. Çapar ID, Arslan H, Akcay M, Uysal B. Effects of protaper universal, protaper next, and hyflex instruments on crack formation in dentin. J Endod. 2014;40(9):1482-84. http:// dx.doi.org/10.1016 / j.joen.2014.02.026

18. Dedeus G, Belladonna FG, Marins J, Silva EJNL, Neves A, Souza $E$, et al. On the causality between dentinal defects and root canal preparation: a micro-ct assessment. Braz Dent J. 2016;27(6):664-669. http://dx.doi.org/10.1590/0103-64402 01601002

19. Kumar ARP, Shemesh $H$, Chang J W-W, Bhowmik A, Sibi S, Gopikrishna $V$, et al. Preexisting dentinal microcracks in nonendodontically treated teeth: an ex vivo micro-computed tomographic analysis. J Endod. 2017;43(6):896-900. http:// dx.doi.org/10.1016/j.joen.2017.01.026

20. Coelho MS, Card SJ, Tawil PZ. Light-emitting diode assessment of dentinal defects: the role of presumed extraction forces. Restor Dent Endod. 2017;42(3):232-39. http://dx.doi.org/10.53 95/rde.2017.42.3.232

21. Jameson M, Hood J, Tidmarsh B. The effects of dehydration and rehydration on some mechanical properties of human dentine. J Biomech. 1993;26(9):1055-1065. http://dx.doi.org/10. 1016/S0021-9290(05)80005-3

22. Bajaj D, Sundaram N, Nazari A, Arola D. Dehydration and fatigue crack growth in dentin. Biomaterials. 2006;27(11):2507-2517. http://dx.doi.org/10.1016/j.biomaterials.2005.11.035

23. De-Deus G, Carvalhal JCA, Belladonna FG, Silva EJNL, Lopes RT, Moreira Filho RE. et al. Dentinal Microcrack Development after Canal Preparation: A Longitudinal in situ Micro-Computed Tomography Study Using a Cadaver Model. J Endod. 2017;43(9):1553-58. http://dx.doi.org/10.1016/j.joen. 2017.04.027

24. White JM, Goodis HE, Marshall SJ, Marshall GW. Sterilization of teeth by gamma radiation. J Dent Res. 1994;73(9):1560-67. http://dx.doi.org/10.1177 / 00220345940730091201

25. Michaud PL, Maleki M, Mello I. Effect of different disinfection/ sterilization methods on risk of fracture of teeth used in preclinical dental education. J Dent Educ. 2018;82(1):84-87. http://dx.doi.org/10.21815/JDE.018.012

Received on: 18/6/2018 Final version resubmitted on: 30/10/2018 Approved on: 19/11/2018 